\title{
Distribution and Dietary Induction of Cellular Retinol-Binding Protein Type II along the Villus-Crypt Axis of the Rat Jejunum
}

\author{
Yuko OGURA $^{1}$, Hiromitsu Yasutake ${ }^{1}$, Kazuki MochIZUKI ${ }^{1}$, Saori YoshiKaWA ${ }^{1}$, \\ Kazuhito Suruga ${ }^{2}$, Hiroshi SugrYama ${ }^{3}$, Sachiko TAKASE ${ }^{2}$ and Toshinao GodA ${ }^{1, *}$ \\ ${ }^{1}$ Laboratory of Nutritional Physiology and the Global COE Program, School of Food and Nutritional Sciences, \\ The University of Shizuoka, 52-1 Yada, Suruga-ku, Shizuoka 422-8526, Japan \\ ${ }^{2}$ Department of Nutrition and Health Sciences, Siebold University of Nagasaki, Nagasaki 851-2195, Japan \\ ${ }^{3}$ Fundamental Research Laboratory, Asahi Breweries, Ltd., 1-21 Midori 1-chome, Moriya, \\ Ibaraki 302-0106, Japan
}

(Received August 1, 2007)

\begin{abstract}
Summary Cellular retinol-binding protein type II (CRBPII) is exclusively expressed in the small intestinal absorptive cells. We previously reported that dietary fat induces CRBPII expression within $12 \mathrm{~h}$ of fat intake. To examine at which locus of the villus-crypt axis this response to dietary fat occurs, 6 -wk-old rats were fed a low-fat diet ( $7 \%$ energy) for $7 \mathrm{~d}$, and then given free access to a high-fat diet (70\% energy) for the subsequent 12, 24 or $48 \mathrm{~h}$. Cryostat sectioning of jejunal segments followed by RNA blot hybridization of the transcripts revealed that CRBPII mRNA was expressed maximally in the lower villus, and the immunoreactive protein of CRBPII was expressed maximally in the mid-villus. Feeding the highfat diet caused a pronounced increase in CRBPII mRNA level from the lower- to middle-villus within $12 \mathrm{~h}$. These results suggest that the CRBPII gene is maximally expressed in the lower villus, and that dietary fat causes an enhancement of CRBPII gene expression in the villus cells.
\end{abstract}

Key Words CRBPII, high-fat diet, rats, villus, crypt

Cellular retinol-binding protein type II (CRBPII) is exclusively expressed in the small intestinal villus cells and plays a pivotal role in intestinal absorption and metabolism of retinol and $\beta$-carotene. CRBPII not only directs retinal reductase to convert retinal to retinol in enterocytes, but also directs lecithin:retinol acyltransferase (L-RAT) to convert retinol to retinyl esters, which leads to incorporation of vitamin A into chylomicron (1). Like many other genes involved in intestinal nutrient absorption (2-5), the CRBPII gene is thought to be expressed at certain stages of the differentiation or maturation of intestinal absorptive cells, which are derived from intestinal stem cells in the crypt and continuously differentiate into the cells destined for nutrient absorption. We have previously demonstrated that CRBPII protein and the enzyme activities involved in vitamin A absorption, e.g. $\beta$-carotene cleavage enzyme, retinal reductase and L-RAT, are coordinately expressed along the villus-crypt axis in the small intestine $(6,7)$. However, the precise distribution of CRBPII mRNA along the villus-crypt axis was unclear. We previously showed that the distribution of the gene transcripts for lactasephlorizin hydrolase (LPH) is more apical and broader than that of sucrase-isomaltase (SI) along the crypt-villus axis, and that dietary sucrose specifically enhances SI mRNA level in the lower villus and LPH mRNA level in the middle and upper villi (5). These results suggest

*To whom correspondence should be addressed.

E-mail: gouda@fns1.u-shizuoka-ken.ac.jp that nutrients enhance intestinal gene expression in specific phase(s) of differentiation in absorptive cells along the villus-crypt column. Our previous studies showed that dietary fat is a major regulator of CRBPII gene expression $(8,9)$, and that the fat-induced increase in CRBPII mRNA occurs within $12 \mathrm{~h}$ of fat exposure, via one of the nuclear receptors, $\operatorname{PPAR} \alpha(10$, 11). It is most likely that expression of the CRBPII gene is regulated by dietary fat at a certain stage of maturation in the absorptive cells. However, it is unclear at which region along the villus-crypt axis of the jejunum the CRBPII expression is induced by dietary fat.

In this study, we employed the cryostat slicing technique to quantitatively determine the distribution of CRBPII mRNA level along the villus-crypt axis of the jejunum of rats which were fed either a low-fat diet $(7 \%$ fat as energy) or high-fat diet (70\% fat as energy).

\section{MATERIALS AND METHODS}

Animals and diet. Six-week-old male Sprague-Dawley (SD) rats (Japan SLC, Hamamatsu, Japan) had free access to a standard chow diet (MF; Oriental Yeast, Co., Ltd., Tokyo, Japan) and water until the experiment began. To examine the basal localization of CRBPII mRNA along the villus-crypt columns the rats were killed at 10:00 a.m. To investigate the diet-induced changes in the expressions of the CRBPII gene and protein, rats were fed a low-fat diet ( $7 \%$ energy as corn oil) for $7 \mathrm{~d}$, and they were subsequently given free access to a high-fat diet (70\% energy as corn oil) for 12, 24 or 
Table 1. The composition of diets $(\mathrm{g} / \mathrm{kg})$.

\begin{tabular}{lcc}
\hline \multicolumn{1}{c}{ Ingredient } & Low-fat-diet & High-fat-diet \\
\hline Vitamin-free casein & 157 & 159 \\
Corn starch & 526 & 36 \\
Corn oil & 24 & 247 \\
Mineral mix & 28 & 28 \\
Vitamin mix & 8 & 8 \\
DL-Methionine & 2.4 & 2.4 \\
Choline bitartrate & 1.6 & 1.6 \\
2\% agar & 254 & 518 \\
Total & 1,000 & 1,000 \\
\hline
\end{tabular}

${ }^{a}$ AIN-76 mineral mix and AIN-76 vitamin mix (1977) purchased from Oriental Yeast, Co., Ltd., Tokyo, Japan.

$48 \mathrm{~h}$. The composition of the diets is shown in Table 1. The rats were killed by decapitation at 10:00 a.m. to avoid any variation in intestinal gene expression due to circadian fluctuation. The experimental procedures used in the present study met the guidelines of the animal usage committee of the University of Shizuoka.

Tissue preparation. The entire small intestine was removed, and the duodenum extending from the pylorus to the ligament of Treitz was discarded. The jejunoileum was divided into three segments of equal length. The proximal one-third (jejunum) of the jejunoileum was flushed with diethylpyrocarbonate (DEPC)-treated, ice-cold $0.154 \mathrm{~mol} / \mathrm{L}$ of $\mathrm{NaCl}$ solution. A 1-cm segment (100 mg) was excised from the middle region of the jejunal segment, and total RNA was extracted. An adjacent segment $(2 \mathrm{~cm})$ was separated into two parts, one of which was opened longitudinally, flattened on a glass slide, serosal-side down, frozen in liquid nitrogen, and immediately subjected to cryostat sectioning. A frozen tissue block of $7 \times 7 \mathrm{~mm}^{2}$ was covered with a supporting medium (OCT Compound, Miles Laboratories, Elkhart, IN, USA) and transferred, serosal-side down, to a pre-flattened supporting surface of $1 \mathrm{~g} / \mathrm{L}$ agar within a cryostat at $-18^{\circ} \mathrm{C}$. The tissue was sectioned transversely at $10 \mu \mathrm{m}$ thickness through the submucosa into the muscular layer as described previously (12). Sections taken from various depths in the villus-crypt column were attached to microscope slides and examined for the presence of villus and crypt architecture after staining with $3 \mathrm{~g} / \mathrm{L}$ methylene blue. The other segment was fixed in 4\% paraformaldehyde/phosphate buffer $\left(18.4 \mathrm{mmol} / \mathrm{L} \quad \mathrm{NaH}_{2} \mathrm{PO}_{4}, 61.1 \mathrm{mmol} / \mathrm{L}\right.$ $\mathrm{Na}_{2} \mathrm{HPO}_{4}$, pH 7.4) and dehydrated in ethanol. This tissue was used for immunohistochemical and in situ hybridization experiments. The mucosa was scraped from the remaining part of the jejunal segment with a glass microscope slide. The intestinal mucosa was homogenized in $4 \mathrm{vol} / \mathrm{wt}$ of ice-cold $10 \mathrm{mmol} / \mathrm{L}$ sodium phosphate $/ 140 \mathrm{mmol} / \mathrm{L} \mathrm{NaCl}(\mathrm{pH} 7.2)$, containing $0.1 \mathrm{mmol} / \mathrm{L}$ phenylmethyl sulfonyl fluoride. After centrifugation of homogenates at $105,000 \times g$ for $1 \mathrm{~h}$ $\left(4^{\circ} \mathrm{C}\right)$, the clear supernatant fraction (cytosol) was frozen at $-20^{\circ} \mathrm{C}$ and used for assay of CRBPII.

RNA extraction and RNA blot hybridization. To deter- mine CRBPII mRNA levels along the villus-crypt columns, 20 consecutive sections were combined and homogenized in $200 \mu \mathrm{L}$ of $25 \mathrm{mmol} / \mathrm{L}$ sodium citrate buffer ( $\mathrm{pH}$ 7.0) containing $4 \mathrm{~mol} / \mathrm{L}$ guanidine thiocyanate, $17 \mathrm{mmol} / \mathrm{L}$ sodium $\mathrm{N}$-lauroylsarcosine and $13 \mathrm{mmol} / \mathrm{L}$ mercaptoethanol, using a polytron homogenizer at 15,000 rpm for $15 \mathrm{~s}$. The homogenate was immediately subjected to RNA extraction, as described by Chomczynski and Sacchi (13). Dot-blot analysis was performed using the ${ }^{32} \mathrm{P}$-labeled cDNA probe for rat CRBPII as described previously (5). Control hybridization was carried out for $\beta$-actin.

Immunological assays. To assay the immunoreactivity of CRBPII at different heights of the villus-crypt columns, tissue blocks were sectioned as described above, and 10 consecutive sections were combined and homogenized in $1 \mathrm{~mL}$ of $10 \mathrm{mmol} / \mathrm{L}$ sodium phosphate/ $140 \mathrm{mmol} / \mathrm{L} \mathrm{NaCl}(\mathrm{pH} 7.2)$ by sonication at $4^{\circ} \mathrm{C}$ for $30 \mathrm{~s}$ using a Branson Sonifier 250 (Branson Sonic Power, Danbury, CT, USA) at dial position 3. The homogenate was centrifuged at $4^{\circ} \mathrm{C}$ at $105,000 \times g$ for $60 \mathrm{~min}$, and the resulting supernatant was stored at $-20^{\circ} \mathrm{C}$. The amounts of CRBPII were measured by enzyme-linked immunosorbent assay with a mono-specific antiserum, as described previously (14).

Immunohistochemical analysis. Immunohistochemical analysis was performed using an ABC high-HRP immunostaining kit (Toyobo, Tokyo, Japan), according to the manufacturer's instructions. Tissue sections were deparaffinized in xylene and ethanol, and incubated for 30 min in a $1: 200$ dilution of rabbit anti-rat CRBPII in PBS containing normal goat serum (14). After rinsing in PBS three times for 5 min each, sections were incubated for $30 \mathrm{~min}$ in a $1: 100$ dilution of biotin-conjugated goat anti-rabbit IgG in PBS, mounted in glycerol and photographed. To verify the specificity of immunostaining, companion sections were processed as above using rabbit pre-immune serum.

In situ hybridization. As the cRNA probe of rat CRBPII for in situ hybridization, a fragment corresponding to +1 to +303 from the transcription start site (15) was prepared using rat CRBPII cDNA cloned in pGEMTeasy as a template. Antisense and sense riboprobes were labeled with digoxigenin using a DIG RNA labeling kit (Roche Molecular Biochemicals, Tokyo, Japan), according to the manufacturer's instructions. Tissue sections were deparaffinized in xylene and ethanol and treated with $0.2 \mathrm{~mol} / \mathrm{L} \mathrm{HCl}$ for $8 \mathrm{~min}, 0.1 \mathrm{~mol} / \mathrm{L}$ triethanolamine-HCl ( $\mathrm{pH} 8.0)$ for $1 \mathrm{~min}$ and $0.26 \%(\mathrm{v} / \mathrm{v})$ acetic anhydride in $0.1 \mathrm{~mol} / \mathrm{L}$ triethanolamine $(\mathrm{pH} 8.0)$ for $15 \mathrm{~min}$. After rinsing for $10 \mathrm{~min}$ with $2 \times \mathrm{SSC}(0.03$ $\mathrm{mol} / \mathrm{L}$ sodium citrate, $0.3 \mathrm{~mol} / \mathrm{L} \mathrm{NaCl}, \mathrm{pH} 7.0$ ), the sections were incubated with a hybridization solution which contained $6 \mathrm{ng} / \mu \mathrm{L}$ DIG-labeled probe in hybridization buffer $(50 \%(\mathrm{v} / \mathrm{v})$ formamide, $2 \times \mathrm{SSC}, 10 \%(\mathrm{w} /$ v) dextran sulfate, $1 \mu \mathrm{g} / \mu \mathrm{L}$ yeast t-RNA, $1 \mu \mathrm{g} / \mu \mathrm{L}$ sonicated salmon sperm DNA and $1 \mu \mathrm{g} / \mu \mathrm{L} \mathrm{BSA}$ ) at $50^{\circ} \mathrm{C}$ for $16 \mathrm{~h}$. After hybridization, the slides were sequentially washed with $5 \times \mathrm{SSC}(0.075 \mathrm{~mol} / \mathrm{L}$ sodium citrate, $0.75 \mathrm{~mol} / \mathrm{L} \mathrm{NaCl}, \mathrm{pH} 7.0$ ) solution at $60^{\circ} \mathrm{C}$ for $10 \mathrm{~min}$, 
A

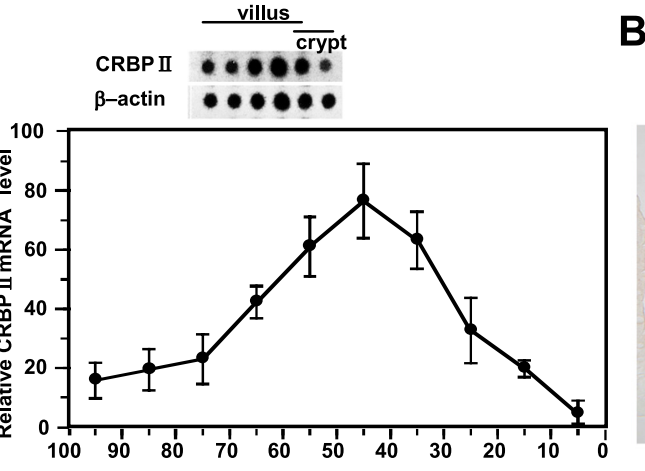

C

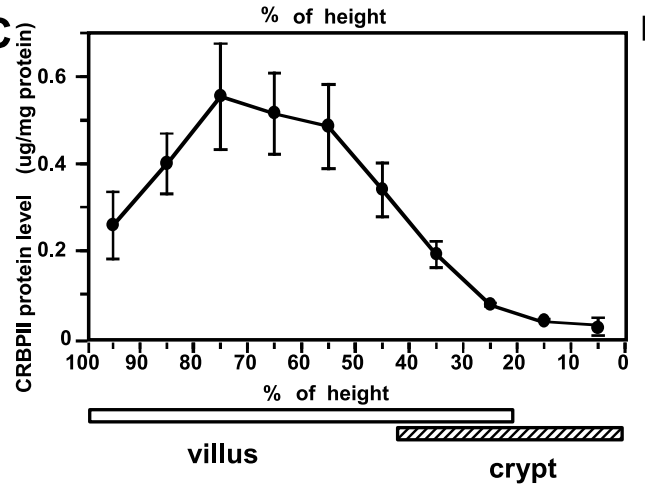

B
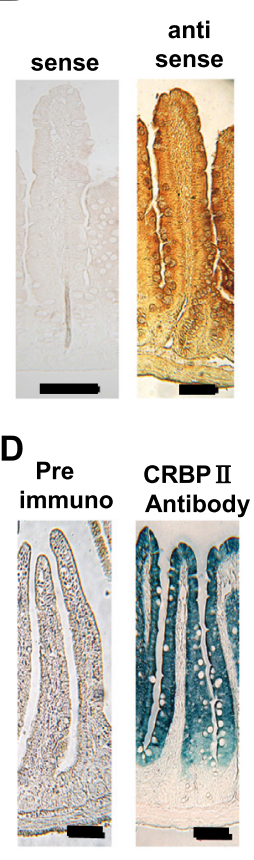

Fig. 1. Distribution of CRBPII mRNA and the immunoreactive CRBPII protein along the villus-crypt axis of the rat jejunum. Rats had free access to a laboratory chow diet throughout the experimental period. (A) Dot blots for CRBPII mRNA in serial sections of villus-crypt columns and the graphic representation of the distribution of CRBPII mRNA along the villus-crypt axis of the rat jejunum. Total RNA was extracted from serial sections of the jejunal segments, and $600 \mathrm{ng}$ of total RNA were subjected to dot-blot hybridization. Autoradiographic images were quantified using an image analyzer, and the results for each sample, normalized for $\beta$-actin mRNA abundance, were expressed as arbitrary units. The abscissa depicts the total height of the intestinal wall, with $100 \%$ representing the top part of the villus and $0 \%$ the bottom part of the serosal side. Values represent means \pm SE, $n=4$. Relative positions of the villus and crypt are depicted with rectangles. (B) In situ hybridization of CRBPII mRNA using DIG-labeled CRBPII antisense or sense RNA. Bars=100 $\mu \mathrm{m}$. (C) Distribution of CRBPII levels along the villus-crypt axis measured using ELISA. Immunoreactive CRBPII protein was normalized for total protein abundance. Abscissa depicts the total height of the intestinal wall, with $100 \%$ representing the top part of the villus and $0 \%$ the bottom part of the serosal side. Values are means \pm SE, $n=4$. (D) Immunohistochemical analysis of jejunal CRBPII protein. Bars $=100 \mu \mathrm{m}$.

$50 \%(\mathrm{v} / \mathrm{v})$ formamide $/ 2 \times \mathrm{SSC}$ at $60^{\circ} \mathrm{C}$ for $30 \mathrm{~min}$ and TNE buffer $(0.5 \mathrm{~mol} / \mathrm{L} \mathrm{NaCl}, 10 \mathrm{mmol} / \mathrm{L}$ Tris-HCl, $\mathrm{pH}$ $7.6)$ at $37^{\circ} \mathrm{C}$ for $10 \mathrm{~min}$. The sections were then treated with RNase A $(2 \mu \mathrm{g} / \mathrm{mL})$ in TNE buffer at $37^{\circ} \mathrm{C}$ for $30 \mathrm{~min}$, followed by washing with TNE buffer at $37^{\circ} \mathrm{C}$ for $30 \mathrm{~min}$, with $2 \times \mathrm{SSC}$ at $48^{\circ} \mathrm{C}(30 \mathrm{~min}$, twice) and $0.2 \times \mathrm{SSC}$ at $48^{\circ} \mathrm{C}(30 \mathrm{~min}$, twice). After washing with

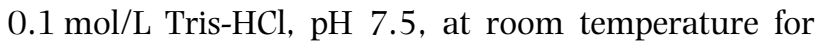
$10 \mathrm{~min}$, the slides were incubated with a blocking buffer containing $1 \%(\mathrm{w} / \mathrm{v})$ blocking reagent (Roche) in $0.1 \mathrm{~mol} / \mathrm{L}$ Tris-HCl, $\mathrm{pH} 7.5$, at room temperature for $60 \mathrm{~min}$. The slides were incubated for $18 \mathrm{~h}$ at $4^{\circ} \mathrm{C}$ with a blocking buffer containing anti-digoxigenin-AP, Fab fragments (Roche). These slides were washed four times with $0.1 \mathrm{~mol} / \mathrm{L}$ Tris-HCl, pH 7.5, for $10 \mathrm{~min}$ and soaked in buffer containing $0.1 \mathrm{~mol} / \mathrm{L}$ Tris, $0.1 \mathrm{~mol} / \mathrm{L} \mathrm{NaCl}$ and $0.2 \mathrm{~mol} / \mathrm{L} \mathrm{MgCl}_{2}, \mathrm{pH} \mathrm{9.5}$, at room temperature for $5 \mathrm{~min}$. Finally, immunoreactivity of sections was visualized by incubating for $18 \mathrm{~h}$ at $4^{\circ} \mathrm{C}$ with $450 \mu \mathrm{g}$ Nitroblue tetrazolium chloride (NBT)/175 $\mu \mathrm{g}$ 5-bromo4-chloro-3-indolyl-phosphate, 4-toluidine salt (BCIP) solution in $1 \mathrm{~mL}$ of buffer containing $0.1 \mathrm{~mol} / \mathrm{L}$ Tris, $0.1 \mathrm{~mol} / \mathrm{L} \mathrm{NaCl}$ and $0.2 \mathrm{~mol} / \mathrm{L} \mathrm{MgCl}_{2}$, pH 9.5.
Statistical analysis. All results were subjected to one-way ANOVA. Differences in mean values at the same height of the villus-crypt columns among groups were tested using Tukey's multiple range test and were considered significant at $p<0.05$.

\section{RESULTS}

Distribution of CRBPII expression along the villus-crypt axis of the rat jejunum

To quantitatively compare expression of CRBPII along the jejunal villus-crypt axis, segments were fractionated along the axis using cryostat sectioning. First, we extracted total RNA from fractions taken from various heights in the villus-crypt columns and quantified the CRBPII mRNA by RNA dot-blot hybridization (Fig. 1A). Dot-blot analysis showed that the CRBPII mRNA level was markedly elevated at the base of the villi, reaching a maximum at the lower villus. It reached a maximum level at $45 \%$ of the height of the villus-crypt columns, and gradually declined toward the top of the villi (Fig. 1A). In situ hybridization analysis showed that the CRBPII transcript was strongly expressed from the top of the crypt to the base of the villi (Fig. 1B). We mea- 
sured the distribution of the amount of immunoreactive CRBPII protein along the villus-crypt axis and found that it increased gradually from the base of the villi to the middle-villus region. It reached a maximum level at $75 \%$ of the height of the villus-crypt columns and the CRBPII protein level decreased towards the top of the villi (Fig. 1C). Immunochemistry showed that staining for the CRBPII protein was most dense from the base of the villi to the middle villus region (Fig. 1D).
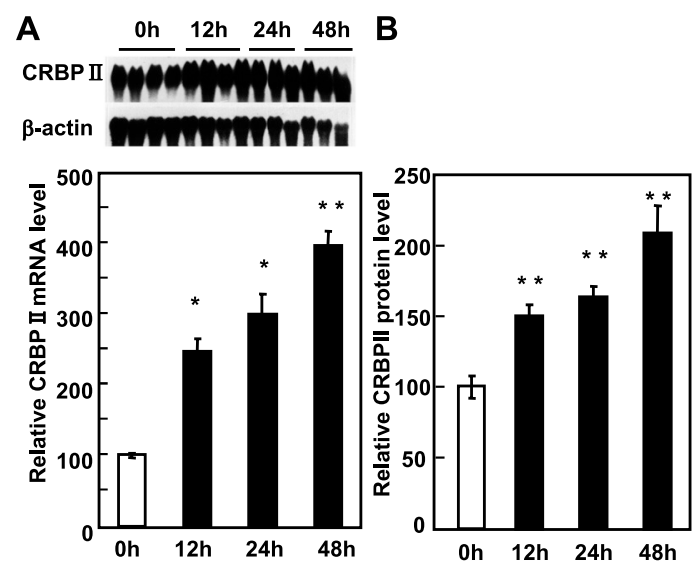

Fig. 2. Effects of dietary fat on CRBPII expression in the rat jejunum. Rats were fed a high-fat diet for 12, 24 and $48 \mathrm{~h}$ after feeding a low-fat diet for $7 \mathrm{~d}$. (A) CRBPII mRNA levels were analyzed by Northern blot hybridization using $20 \mu \mathrm{g}$ jejunal total RNA. CRBPII mRNA levels were normalized by signals of $\beta$-actin mRNA. (B) CRBPII protein levels were measured using ELISA. Values are means \pm SE, $n=4$. Asterisks indicate significant differences compared with the levels in rats at $0 \mathrm{~h}$ $\left({ }^{*} p<0.05,{ }^{* *} p<0.01\right)$.
Effects of dietary fat on CRBPII expression in the rat jejunum

We examined the time-dependent effects of dietary fat on jejunal CRBPII expression. CRBPII mRNA and protein levels were not changed until $3 \mathrm{~h}$ after feeding a high-fat diet (data not shown). However, the levels of CRBPII mRNA and protein increased at 12, 24 or $48 \mathrm{~h}$ after feeding a high-fat diet compared with values at $0 \mathrm{~h}$. CRBPII mRNA levels at 12, 24 and $48 \mathrm{~h}$ had increased 2.5-, 3- and 4-fold, respectively, compared with the level at $0 \mathrm{~h}$ (Fig. 2A). Similarly, CRBPII protein levels at 12, 24 and $48 \mathrm{~h}$ were 1.5-, 1.6- and 2.1-fold greater, respectively, than the level at $0 \mathrm{~h}$ (Fig. 2B).

Dietary fat-induced increases in CRBPII mRNA and protein levels along the villus-crypt columns

To determine at which locus of the villus-crypt axis the CRBPII mRNA levels were elevated following the dietary change from a low-fat diet to a high-fat diet, RNA blot hybridizations were performed using the total RNA extracted from the homogenates of the crypt at sections collected at various heights of the villus-crypt columns. In the control rats fed a low-fat diet (at time 0), CRBPII mRNA peaked at the mid-villus, decreasing both in the lower- and the upper-villus (Fig. 3A). Feeding the high-fat diet caused a significant increase of CRBPII mRNA levels only in the crypt and the lower-villus (i.e. at $15,25,35$ and $45 \%$ of the height of the villus-crypt columns) at $12 \mathrm{~h}$ after the dietary change. In the rats fed the high-fat diet for $24 \mathrm{~h}$ and $48 \mathrm{~h}$, significantly greater CRBPII mRNA levels were also observed in the mid-villus than in the rats fed the low-fat diet. In the rats fed the high-fat diet, maximal CRBPII mRNA levels were attained at $45 \%$ of the overall height of the villus-crypt column, and the CRBPII levels at this loca-

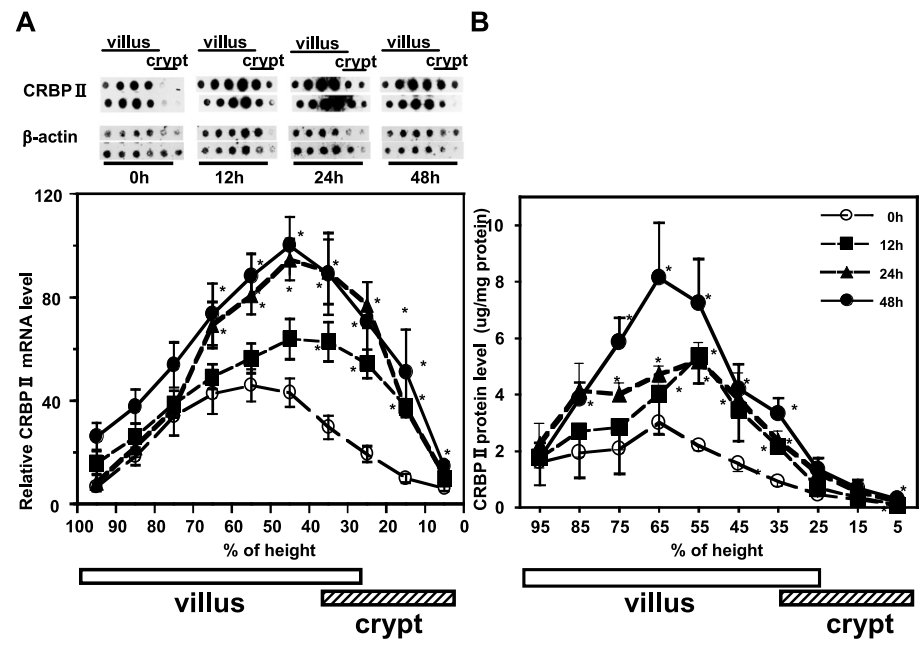

Fig. 3. Effects of dietary fat on CRBPII mRNA levels and the immunoreactive CRBPII protein in second sections of villuscrypt columns of the rat jejunum. Rats were fed a high-fat diet for 12, 24 and $48 \mathrm{~h}$ after feeding on a low-fat diet for $7 \mathrm{~d}$. (A) Dot blots for CRBPII mRNA in serial sections of villus-crypt columns and the graphic representation of the distribution of CRBPII mRNA along the villus-crypt axis of the rat jejunum. Total RNA was extracted from the serial sections of jejunal segments and analyzed for CRBPII mRNA abundance by dot blot hybridization. The results for each sample, normalized for $\beta$-actin mRNA abundance, were expressed as arbitrary units, representing the mean value of the maximal levels along the villus-crypt columns of control animals as $100 \%$. Values are means \pm SE, $n=4$. (B) Distribution of CRBPII levels along the villus-crypt axis measured using ELISA. Immunoreactive CRBPII protein was normalized for total protein abundance. Values are means \pm SE, $n=4$. Asterisks indicate significant differences compared with the levels in rats at $0 \mathrm{~h}\left({ }^{*} p<0.05\right)$. 
tion at 12,24 and $48 \mathrm{~h}$ after being offered a high-fat diet were 1.4-, 2.1- and 2.2-fold greater, respectively, than the control rats fed the low-fat diet (Fig. 3A). CRBPII protein levels in the control rats fed a low-fat diet (at time 0) gradually increased from the base of the villus to the mid-villus region, reaching maximal levels at $65 \%$ of the height of the villus-crypt column, and decreasing to a lower level in the upper villus. In rats fed the high-fat diet for $12 \mathrm{~h}$, CRBPII protein levels were significantly greater only in the lower-villus region than in rats fed the low-fat diet (Fig. 3B). In the rats fed the high-fat diet for $12 \mathrm{~h}$ and $24 \mathrm{~h}$, maximal CRBPII protein levels were attained at $55 \%$ of the height of the villus-crypt column, and decreased towards the top of the villus. Further increases in CRBPII protein levels were observed in the mid-villus in rats fed the high-fat diet for $48 \mathrm{~h}$, and in this case maximal protein levels were found at $65 \%$ of the height of the villus-crypt column, and CRBPII protein levels decreased towards the top of the villus. The CRBPII protein levels at $65 \%$ of the height of the villus-crypt columns at 12, 24 and $48 \mathrm{~h}$ after being offered a high-fat diet were 1.8-, 1.7- and 2.7-fold greater, respectively, than in the control rats at time 0 (Fig. 3B).

\section{DISCUSSION}

In this study, we employed the technique of cryostat sectioning to examine the distribution of CRBPII mRNA in the small intestine of rats which were fed a laboratory chow diet. The dot-blot hybridization of the RNA extracted from the tissue slices, which was obtained at various heights of villus-crypt axis, enabled us to quantitatively determine the distribution of CRBPII mRNA. Results demonstrated that the CRBPII mRNA level was minimal in crypt regions, abruptly elevated at the villus-crypt junction and then gradually declined towards the top of the villi. In addition, using an enzyme-linked immunosorbent assay we showed that the amount of immunoreactive CRBPII protein along the villus-crypt axis was gradually elevated from the base to middle villus region, and decreased toward the top of the villi. This result indicates that CRBPII protein expression is following that of mRNA expression. Many gene products that are characteristic of the differentiated enterocyte are known to be abruptly expressed at the villuscrypt junction; these include the sodium-glucose cotransporter 1 (SGLT1) (16), the fructose transporter GLUT5 (4), aminopeptidase N (2) and liver fatty acidbinding protein (3). These enterocyte-specific genes seem to be separated into two groups in terms of the mRNA distribution along the villus-crypt axis. One group of genes including genes encoding for SI, liver fatty acid-binding protein and aminopeptidase $\mathrm{N}$ were shown to exhibit maximal mRNA accumulation in the lower- to mid-villus regions, followed by a marked decrease in the mRNA levels in the top portions of the villus $(2,3,5)$. Another group of genes including LPH, SGLT1 and glucose transporter 2 (GLUT2) are expressed persistently as the enterocyte migrates up to the villus tip $(5,16)$. The present study suggests that CRBPII belongs to the former group of genes which show a sharp decline in mRNA levels in the upper half of the villus-crypt columns. This result may indicate that the activation of CRBPII gene transcription in the villus cells is transient, being restricted to the lower- to midvillus. The reason why the CRBPII protein is highly expressed at the mid-villus is not clear. Our previous study revealed that the enzyme activities of proteins related to retinol and $\beta$-carotein absorption/digestion in the small intestine such as L-RAT, $\beta$-carotein cleavage enzyme and retinal reductase were also detected at the highest expression levels at the mid-villus (7). It is speculated that retinol/ $\beta$-carotein digestion/absorption related proteins including CRBPII may address their digestion/absorption by synchronously expressing in the villus. The present study extends our previous finding which showed that dietary fat elicited or enhanced the levels of CRBPII mRNA in the rat jejunum $(8,9)$. The high-fat diet induced an increase in CRBPII mRNA as early as $12 \mathrm{~h}$ after consumption (Fig. 2), while it is already confirmed that feeding a low-fat diet does not induce CRBPII gene expression in adult $(8)$ or weaning rats (17). The cryostat slicing technique enables us to determine the precise locus of villus cells where the rapid mRNA accumulation occurred. This study demonstrated that the initial rise in CRBPII mRNA levels was most prominent in the cells which were accumulating the gene transcripts, i.e. at the lower villus. This result suggests that dietary fat enhances the efficiency of transcription of the CRBPII gene. This notion is consistent with our previous studies which used a nuclear run-on assay to show that the transcription of the CRBPII gene is enhanced in rats fed a high-fat diet as compared with those fed a low-fat diet (10). The molecular mechanism underlying the dietary fat-mediated regulation of CRBPII gene expression at the specific regions along the villus-crypt axis is still unclear. We have previously demonstrated that dietary fat, especially unsaturated fatty acids (oleic, linoleic and alpha-linolenic acids), induced CRBPII gene expression in the rat jejunum (9). The rat CRBPII promoter region contains nuclear response elements, i.e. RXRE and RE3. These elements are known to be bound to peroxisome proliferator-activated receptors (PPARs) and retinoid X receptor (RXRs) heterodimers (18). Our recent study demonstrated that long-chain polyunsaturated fatty acids caused conformational changes of $\operatorname{PPAR} \alpha$, which led to parallel increases in both DNA binding to the $\operatorname{PPAR} \alpha-$ response element and DNA binding-independent transactivity (19). Additionally, our previous studies revealed that a diet containing high triacylglycerol with polyunsaturated fatty acids induces gene expression of PPAR $\alpha$ as well as that of CRBPII (20). Furthermore, we have shown not only that the PPAR $\alpha$-RXR heterodimer in nuclei of the jejunum of rats fed a diet containing high triacylglycerol with polyunsaturated fatty acids was strongly bound to CRBPII-RE3 in vitro (10), but also that promoter activity of the CRBPII-promoter and enhancer activity of CRBPII-RE3 co-transfected with $\operatorname{PPAR} \alpha$ and $\operatorname{RXR} \alpha$ were enhanced by linoleic acid and 
arachidonic acid in intestinal cell line Caco-2 cells (21). Thus, it appears likely that the polyunsaturated fatty acids in the high-fat diet stimulate transcription of the CRBPII gene through the activator of $\operatorname{PPAR} \alpha$ in the lower villus cells. The expression of $\operatorname{PPAR} \alpha$ and $\operatorname{RXR} \alpha$ in the villus cells was reported by Braissant et al. (22). They showed by in situ hybridization that $\operatorname{PPAR} \alpha$ transcription was expressed in the small intestine villus cells. We also confirmed by immunohistochemical analysis that both $\operatorname{PPAR} \alpha$ and $\operatorname{RXR} \alpha$ are expressed in the villus cells (unpublished result). Further studies are needed to investigate whether $\operatorname{PPAR} \alpha$ contributes to induction of CRBPII expression by dietary fat along the villus-crypt axis of the rat jejunum.

In conclusion, the results of the present study suggest that the CRBPII gene is maximally expressed in the lower villus, and that dietary fat elicits enhancement of CRBPII gene expression in the villus cells which are accumulating the transcripts.

\section{Acknowledgments}

This work was supported by a Grant-in-Aid for Scientific Research from the Ministry of Education, Culture, Sports, Science and Technology of Japan (09670074, $11670076,18790171)$, a grant from Uehara Memorial Foundation, the COE Program in the 21st Century, the Center of Excellence for Evolutionary Human Health Sciences, from the Ministry of Education, Culture, Sports, Science and Technology of Japan.

\section{REFERENCES}

1) Ong DE. 1984. A novel retinol-binding protein from rat. Purification and partial characterization. J Biol Chem 259: $1476-1482$.

2) Noren O, Dabelsteen E, Hoyer P. E, Olsen J, Sjostrom H, Hansen GH. 1989. Onset of transcription of the aminopeptidase N (Leukemia Antigen Cd 13) gene at the crypt/villus transition zone during rabbit enterocyte differentiation. FEBS Lett 259: 107-112.

3) Iseki S, Kondo H, Hitomi M, Ono T. 1990. Localization of liver fatty acid-binding protein and its mRNA in the liver and jejunum of rats: An immunohistochemical and in situ hybridization study. Mol Cell Biochem 98: 27-33.

4) Rand EB, Depaoli AM, Davidson NO, Bell GI, Burant CF. 1993. Sequence, tissue distribution, and functional characterization of the rat fructose transporter GLUT5. Am J Physiol 264: G1169-1176.

5) Goda T, Yasutake H, Tanaka T, Takase S. 1999. Lactasephlorizin hydrolase and sucrase-isomaltase genes are expressed differently along the villus-crypt axis of rat jejunum. J Nutr 129: 1107-1113.

6) Goda T, Pacifici M, Takase S. 1993. Induction and distribution of cellular retinol-binding protein, type two during villus-crypt development in the chick duodenum. Biol Neonate 64: 392-398.

7) Tajima S, Goda T, Takase S. 1999. Coordinated distribution patterns of three enzyme activities involved in the absorption and metabolism of beta-carotene and vitamin A along the villus-crypt axis of chick duodenum. Life Sci 65: 841-848.

8) Takase S, Tanaka K, Suruga K, Kitagawa M, Igarashi M, Goda T. 1998. Dietary fatty acids are possible key deter- minants of cellular retinol-binding protein II gene expression. Am J Physiol 274: G626-632.

9) Suruga K, Suzuki R, Goda T, Takase S. 1995. Unsaturated fatty acids regulate gene expression of cellular retinol-binding protein, type II in rat jejunum. J Nutr 125: 2039-2044.

10) Suruga K, Mochizuki K, Kitagawa M, Goda T, Horie N, Takeishi K, Takase S. 1999. Transcriptional regulation of cellular retinol-binding protein, type II gene expression in small intestine by dietary fat. Arch Biochem Biophys 362: 159-166.

11) Suruga K, Mochizuki K, Suzuki R, Goda T, Takase S. 1999. Regulation of cellular retinol-binding protein type II gene expression by arachidonic acid analogue and 9-cis retinoic acid in Caco-2 cells. Eur J Biochem 262: 70-78.

12) Goda T, Yamada K, Bustamante S, Koldovsky O. 1983. Dietary-induced rapid decrease of microvillar carbohydrase activity in rat jejunoileum. Am J Physiol 245: G418-423.

13) Chomczynski P, Sacchi N. 1987. Single-step method of RNA isolation by acid guanidinium thiocyanate-phenol-chloroform extraction. Anal Biochem 162: 156159.

14) Takase S, Goda T, Shinohara H. 1993. Adaptive changes of intestinal cellular retinol-binding protein, type II following jejunum-bypass operation in the rat. Biochim Biophys Acta 1156: 223-231.

15) Li E, Demmer LA, Sweetser DA, Ong DE, Gordon JI. 1986. Rat cellular retinol-binding protein II: Use of a cloned cDNA to define its primary structure, tissue-specific expression, and developmental regulation. Proc Natl Acad Sci USA 83: 5779-5783.

16) Hwang ES, Hirayama BA, Wright EM. 1991. Distribution of the SGLT1 $\mathrm{Na}^{+}$/glucose cotransporter and mRNA along the crypt-villus axis of rabbit small intestine. Biochem Biophys Res Commun 181: 1208-1217.

17) Mochizuki K, Mochizuki H, Kawai H, Ogura Y, Shimada M, Takase S, Goda T. 2007. Possible role of fatty acids in milk as the regulator of the expression of cytosolic binding proteins for fatty acids and vitamin A through PPAR $\alpha$ in developing rats. J Nutr Sci Vitaminol 53: 515521.

18) Takase S, Suruga K, Goda T. 2000. Regulation of vitamin A metabolism-related gene expression. Br J Nutr $\mathbf{8 4}$ (Suppl 2): S217-221.

19) Mochizuki K, Suruga K, Fukami H, Kiso Y, Takase S, Goda T. 2006. Selectivity of fatty acid ligands for PPAR $\alpha$ which correlates both with binding to cis-element and DNA binding-independent transactivity in Caco-2 cells. Life Sci 80: 140-145.

20) Mochizuki K, Suruga K, Kitagawa M, Takase S, Goda T. 2001. Modulation of the expression of peroxisome proliferator-activated receptor-dependent genes through disproportional expression of two subtypes in the small intestine. Arch Biochem Biophys 389: 41-48.

21) Suruga K, Kitagawa M, Yasutake H, Takase S, Goda T. 2005. Diet-related variation in cellular retinol-binding protein type II gene expression in rat jejunum. Br J Nutr 94: $890-895$.

22) Braissant O, Foufelle F, Scotto C, Dauca M, Wahli W. 1996. Differential expression of peroxisome proliferatoractivated receptors (PPARs): Tissue distribution of PPAR- $\alpha,-\beta$, and $-\gamma$ in the adult rat. Endocrinology 137: 354-366. 